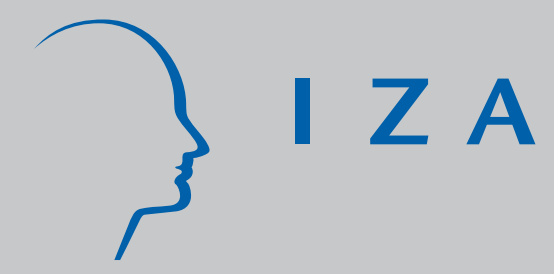

IZA DP No. 3739

Testing Mundell's Intuition of Endogenous OCA Theory

Thierry Warin

Phanindra V. Wunnava

Hubert P. J anicki

September 2008 


\title{
Testing Mundell's Intuition of Endogenous OCA Theory
}

\author{
Thierry Warin \\ Middlebury College \\ Phanindra V. Wunnava \\ Middlebury College \\ and IZA
}

Hubert P. Janicki

Arizona State University

Discussion Paper No. 3739

September 2008

\author{
IZA \\ P.O. Box 7240 \\ 53072 Bonn \\ Germany \\ Phone: +49-228-3894-0 \\ Fax: +49-228-3894-180 \\ E-mail: iza@iza.org
}

\begin{abstract}
Any opinions expressed here are those of the author(s) and not those of IZA. Research published in this series may include views on policy, but the institute itself takes no institutional policy positions.

The Institute for the Study of Labor (IZA) in Bonn is a local and virtual international research center and a place of communication between science, politics and business. IZA is an independent nonprofit organization supported by Deutsche Post World Net. The center is associated with the University of Bonn and offers a stimulating research environment through its international network, workshops and conferences, data service, project support, research visits and doctoral program. IZA engages in (i) original and internationally competitive research in all fields of labor economics, (ii) development of policy concepts, and (iii) dissemination of research results and concepts to the interested public.
\end{abstract}

IZA Discussion Papers often represent preliminary work and are circulated to encourage discussion. Citation of such a paper should account for its provisional character. A revised version may be available directly from the author. 
IZA Discussion Paper No. 3739

September 2008

\section{ABSTRACT}

\section{Testing Mundell's Intuition of Endogenous OCA Theory*}

This paper presents an empirical assessment of the endogenous optimum currency area theory. Frankel and Rose (1998) study the endogeneity of a currency union through the lens of international trade flows. Our study extends Frankel and Rose's model by using FDI flows to test the original theory developed by Mundell in 1973. A gravity model is used to empirically assess the effectiveness of the convergence criteria by examining location specific advantages that guide multinational investment within the European Union. A fixed effects model based on a panel data of foreign direct investment (FDI) flows within the EU-15 shows that horizontal investment promotes the diffusion of the production process across the national border. Specifically, our results suggest that economic convergence ensured by belonging to the common currency area helps double FDI flows.

JEL Classification: $\quad$ C23, C52, F15

Keywords: economic integration, gravity model, endogenous optimum currency area

Corresponding author:

Phanindra V. Wunnava

Department of Economics

Middlebury College

Warner Hall 502F

Middlebury, VT 05753

USA

Email:wunnava@middlebury.edu

\footnotetext{
* The authors thank seminar participants at the Southern Economic Association Annual Conference (Washington, D.C) in November, 2005 for comments on an earlier draft. We also would like to thank Brenda Ellis, and Joseph Toth Jr. for their valuable editorial suggestions, and Pavel Svaton for his timely research assistance. The views expressed herein are the authors' and the usual caveats apply. Part of this research was completed while Warin was a Visiting Scholar at the Minda de Gunzburg CES, Harvard University in 2005.
} 


\section{I. \\ Introduction}

In a recent article, McKinnon (2004) brings attention to a little-known article by Mundell (1973b) that argues that optimal risk-sharing is attained when countries exhibit a wide degree of heterogeneity. This paper is indeed the major latest refinement, if not a correction of the Optimum Currency Area (OCA) theory, initiated by Mundell (1961) himself. Before this paper, Mundell argued that an economic area has to be optimal before using a common currency or a fixed exchange-rate mechanism. The causality is reversed in 1973 since using a common currency or joining a fixed exchange-rate mechanism may help an economic area become optimal. Thus, there is a chronological anteriority of what is Mundell's intuition in 1973 over what will become known as the Endogenous Optimum Currency Area theory (Frankel and Rose 1998). The goal of our paper is twofold. First, we want to provide an empirical assessment of Mundell's intuition using the Economic and Monetary Union (EMU) as an example. Second, we want to emphasize that Mundell's intuition is already a good answer to what will become a debate on two definitions of economic convergence between Krugman (1993) on the one hand and the European Commission on the other hand (European Commission 1990).

The paper McKinnon refers to was published in 1973 and is part of two prescient papers by Mundell (1973a) on the advantages of common currencies presented at a conference in Madrid in 1970 on optimum currency areas. According to McKinnon (2004), "Perhaps in part because the conference proceedings were not published until 1973, these papers have been overshadowed by his 1960s masterpieces." The economic literature seems to have forgotten the refinements and the new directions these two papers were giving to the brand new literature on optimal currency areas. McKinnon regrets: "The first of these papers 'Uncommon Arguments for Common Currencies' is of great intrinsic interest because very early on it emphasized the forward-looking nature of the foreign exchange market which was then worked out in more analytical detail by his students: see, e.g. Frenkel and Mussa (1980)." In other words, it was already embodying the endogeneity of the optimality of a currency area. Already in 1973, Mundell has this intuition that will become a concept in 1998 with Frankel and Rose (1998).

McKinnon notes that "As such, it counters the earlier Mundell idea that asymmetric shocks - i.e. those where an unexpected disturbance to national output affects one country differently from another - undermine the case for a common currency. Instead, Mundell II showed how having a common 
currency across countries can mitigate such shocks by better reserve pooling and portfolio diversification. Under a common currency, a country suffering an adverse shock can better share the loss with a trading partner because both countries hold claims on each other's output."

According to Mundell's arguments, in the absence of capital controls, credibly fixed exchange rates would encourage international portfolio diversification to share the risks from asymmetric economic shocks (McKinnon 2004). This would, in turn, reduce asynchronous economic shocks helping the creation of an OCA, thus allowing the OCA to arise endogenously. Mundell's intuition in 1973 over the causality of an OCA is based on allocation of capital. Later, Frankel and Rose (1998) and Frankel (1999) twig the concept of "endogenous" optimum currency area: "The OCA criterion might be satisfied ex post even if not ex ante" (Frankel 1999). They relate this endogeneity to trade integration and show that trade integration reduces the likelihood of asynchronous economic shocks (Frankel and Rose 1998). McKinnon (2004): "The presence of asynchronous demand shocks, or asynchronous fluctuations more generally, could well diminish as trade integration increases. Of course, under a common currency, asynchronous demand shocks would quite minor because of the disappearance of separate national monetary policies."

In 2003, Ching and Devereux (2003) considers Mundell's intuition in 1973 to examine from a theoretical perspective the tradeoff between the adjustment benefits of a flexible exchange rate on the one hand, and the risksharing benefits of a single currency area on the other hand as in Mundell (1973). Our study wants to bring empirical evidence to Mundell's intuition and uses the EMU as an illustration. We examine to what extent the transition to the Euro endogenously affected the allocation of capital across the European Union.

Europe designed institutions to assure economic convergence prior the introduction of the Euro abiding by a strict definition of the OCA theory. Initiated in 1993, the Maastricht Treaty set out strict guidelines for member states to follow with the ultimate goal of adopting a single currency. The adoption of the common currency in 1999 concluded the European convergence process.

The Maastricht Treaty serves as the blueprint for the eventual adoption of a common currency and identifies several macroeconomic convergence policies to be satisfied by all candidate countries before entrance into the European Monetary Union (EMU). The treaty presents the following convergence criteria: 
1. candidate country inflation is no more than $1.5 \%$ above the average of the lowest three inflation rates in the European Monetary System (EMS);

2. the long-term interest rate of the candidate country is no more than $2 \%$ higher than the average of the low inflation countries in the EMS;

3. the candidate country is a member of the exchange rate mechanism of the EMS and has not observed a devaluation in the two years preceding entrance into the EMU;

4. the candidate country government budget deficit is no higher than $3 \%$ of GDP; and

5. the candidate country government debt does not exceed $60 \%$ of GDP.

Underlying the Maastricht Treaty convergence criteria is the European Commission (1990)'s interpretation of the theory of Optimum Currency Areas first proposed by Mundell (1961a). As we shall see, the five economic criteria in the Treaty of Maastricht are one definition of convergence, and more precisely a macroeconomic definition of convergence.

In order to address the positive or negative externalities of these criteria on the microeconomic level, this study proposes an empirical analysis of the endogenous OCA theory. The first originality of this study is to employ an alternative measure to bilateral trade flows. Indeed, we chose to go back to the first intuition of the endogenous OCA theory found in Mundell (1973b) when he refers to the allocation of capital as a result of the use of a common currency. For this purpose, we will use the bilateral foreign direct investment (FDI) flows as a proxy for the allocation of capital as done in several papers (Razin et al. 2002).

The second originality is in the combination of this micro-approach (Hecksher-Ohlin variables) with the convergence measure (European macroeconomic aggregates). This approach is inspired by Corsetti and Pesenti (2002) who developed a theoretical model dealing with the microstructure of national economies instead of bilateral trade: imperfect competition, nominal rigidities in the goods markets, and forward-looking price-setting by firms.

We employ these microeconomic measures through an empirical analysis using a variation of the gravity model of international trade. Generalized, the gravity model explains a flow from country $i$ to country $j$ by economic forces at the flow's origin, the economic forces at the flows destination, and the forces aiding or resisting the movement of the flow from the origin to the destination.

The organization of the paper is as follows. Section 2 presents background discussion of the endogeneity argument with respect to European integration. 
Section 3 presents the methodology of the gravity model used in this study and its connection to multinational firm theory. Section 4 follows with a discussion of the empirical analysis. Finally, Section 5 provides some possible policy implications and conclusions.

\section{II.}

\section{Background literature}

The political discussions of the late 1970s following the inception of the ECU (European Currency Unit) focused on the likelihood of transforming this complementary currency to existing currencies into a perfect substitute to the same existing currencies.

\subsection{To the origins of the OCA theory}

The OCA theory, first introduced by Mundell (1961) served to frame both the costs and benefits of monetary integration within this political discussion. Since then a vast literature has developed with notable contributions by McKinnon (1963) and Kenen (1969). According to Frankel and Rose (1998), this literature focuses on four inter-relationships between the members of a potential OCA: (1) the extent of trade; (2) the similarity of shocks and cycles; (3) the degree of labor mobility; and (4) the system of risk-sharing, usually through fiscal transfers.

Given the obvious applicability of this theory to European integration, the European Commission (1990) started to work on the steps necessary to enter into an OCA. However, according to Eichengreen (1990), Europe at the time was clearly not an OCA. Consequently, the Treaty of Maastricht was implemented in 1993 in order to force convergence to an OCA prior to adoption of a common currency. Five economic proxies were devised to ensure the convergence on the three public policy dimensions: (1) monetary policy (in a closed and open economy perspective); (2) fiscal policy; and (3) structural policy. The proxies were respectively: inflation, exchange rate, national debt, public deficit, and long-term interest rates.

\subsection{The Endogenous OCA Theory: Mundell's intuition}

Although Europe was arguably not an OCA before the inception of the Euro (Bayoumi and Eichengreen 1993, 1994, 1996), economic literature started to develop an e-OCA theory (to copy molecular scientists who created the OcaB) known as the endogenous optimum currency area theory. According to Frankel and Rose (1998), the "examination of historical data gives a misleading picture of a country's suitability for entry into a currency union, since the OCA criteria are endogenous." In other words, waiting for two 
economies to be in phase before adopting the same currency is only one part of the path towards an OCA since using a common currency will also force the economies to become an OCA.

We can already find a similar argument in Mundell (1973a,b): if countries adopt a common currency without substantial changes to their purchasing parities, and thereby eliminate uncertainty in the exchange rate, then they gain a better allocation of capital. Although this is not yet the endogenous OCA (since Mundell argues that purchasing parities should demonstrate some steadiness over time), he nevertheless emphasizes that gains in terms of allocation of capital are necessary to help create an OCA.

We can also find the e-OCA already in the European Commission (1990)'s report stating that the EMU will reduce the incidence of country-specific shocks.

\subsection{Concerns about convergence: Frankel and Rose's response}

The OCA definition is not related to convergence in business cycles. When policymakers talk about the convergence needed to become an OCA, attention should be paid to the type of convergence being considered. In separating convergence in trade from convergence in business cycles, Krugman (1993) argues that specialization will occur in Europe due to the reduction of transaction costs, which is opposed to the European Commission (1990)'s report. ${ }^{1}$ Mundell's (1961) article is the theoretical basis for the European Commission. Indeed, "This article leans towards making currency areas smaller and more homogenous - rather than larger and more heterogenous" notes McKinnon (2004). As Kenen (1969) pointed out, relatively undiversified, less developed countries, should retain exchange flexibility, and only diversified economies should join a fixed exchange-rate regime, such as Bretton Woods at the time of writing of the chapter. Kenen's conclusion is in line with Mundell (1961a), but not with Mundell (1973b) where Mundell emphasizes the need to promote asset diversification for international risk-sharing. This can also be said for Bayoumi and Eichengreen (1993) and Krugman (1993) who worried that "even a successful monetary and economic union may become less of an optimum currency area over time as its regions naturally become more specialized in what they produce" (McKinnon 2004). According to McKinnon (2004), Kenen's point that undiversified countries retain exchange rate flexibility in order to ameliorate the resulting income fluctuations does not hold. Indeed, "tying the exchange rate to the fortunes of one or two primary products undermines private portfolio diversification and international risk-sharing". Moreover, "once risk-sharing through portfolio

\footnotetext{
${ }^{1}$ For a more detailed presentation of the debate, see De Grauwe (2003).
} 
diversification in bond holding is properly weighed, the case for a monetary union becomes even stronger as the constituent parts of the underlying economic union become more specialized in what they produce. Presumably, the productivity from greater regional specialization is one of the major benefits of having an economic cum monetary union in the first place!" (McKinnon 2004).

Further research like Fontagne and Freudenberg (1999) show using bilateral EU trade during 1980-1994 that the EMU is likely to foster intra-industry trade in Europe, leading to more symmetric shocks between member states. In other words, the monetary union will endogenously create the conditions of its success.

According to Frankel and Rose (1998), endogeneity comes from the fact that "Entry into a currency union may raise international trade linkages ... more importantly, tighter international trade ties can be expected to affect the nature of national business cycles." Further studies, for example Devereux and Engel (2002) or Broda and Romalis (2003), have developed empirical analyses of the e-OCA using trade and exchange rate models. The roots of these studies are in the examination of the two-way interaction between trade pricing and exchange rate volatility proposed by Baldwin and Lyons (1993, 1994).

Another noteworthy point in Frankel and Rose (1998) is the difference between trade and business cycles: "From a theoretical viewpoint, closer international trade could result in either tighter or looser correlations of national business cycles. Cycles could, in principle, become more idiosyncratic. Closer trade ties could result in countries becoming more specialized in the goods in which they have comparative advantage. These countries might then be more sensitive to industry-specific shocks, resulting in more idiosyncratic business cycles. However, if demand shocks (or other common shocks) predominate, or if intra-industry trade accounts for most trade, then business cycles may become more similar across countries when countries trade more."

For this study, we propose an empirical analysis of the e-OCA through the use of a different proxy than the bilateral trade used by Frankel and Rose (1998): the bilateral FDI flows. By doing so, we want to measure Mundell (1973b)'s intuition about the better allocation of capital that would result from the use of a common currency. We use FDI flows as a proxy for the allocation of capital (Razin et al. 2002), and - as in Mundell (1973b)'s argument - we will consider the exchange rates among other variables. This model conforms to the micro-structure approach by Corsetti and Pesenti (2002), as well as De Grauwe and Mongelli (2005)'s “intuition" about the rise of FDI when countries belong to the EMU. 


\section{III. \\ Methodology and data}

We will use a gravity model to analyze bilateral FDI outflows. This model is commonly employed in the study of international trade. FDI is the movement of production activity across the national border. More specifically, FDI is the acquisition of $10 \%$ or more of foreign firm assets. According to Feenstra (1999), this internal activity is significantly different from inter-firm linkages that can be established when independent firms interact. The acquisition of a foreign subsidiary for production or branch distribution includes benefits such as lower trade costs and information costs. Barrel and Pain (1997) argue that FDI is not simply an alternative method to increase firm production capacity, but becomes a channel for the transfer of knowledge capital and transaction technology.

Multinational activity is usually described with reference to ownershipspecific advantages, internalization incentives, and location-specific advantages outlined in Dunning (1981). Ownership-specific advantages refer to a firm's propriety rights or exclusive or favorable access to inputs and factors of production. Internalization incentives include legal safeguards such as absence of price discrimination, institutions that protect property rights, and protection against exploitation through government intervention (e.g., tariffs, tax differences, and quotas) to protect the firm. Locationspecific advantages, the focus of this study, assume firm profitability in producing a product in a foreign country rather than simply producing it at home and exporting to the foreign market. Transport and communications costs are the most obvious examples. Others include input prices, quality and productivity of labor, energy, materials, and intermediate goods as well as the distribution of inputs and markets in the production process of firm operation in the foreign country.

From a theoretical perspective, location advantages can be divided into two competing arguments. The factor proportions hypothesis, presented in Helpman (1984), Markusen (1984), and Helpman and Krugman (1985), states that multinational activity arises only in the presence of sufficient differences in factor endowments among countries. When these differences in factor prices are equalized across borders, no incentives exist for the firm to maintain a foreign center of production. It should be noted that an important limitation to this strand of literature was the assumption of zero transportation costs.

The second argument, known as the proximity-concentration hypothesis (Brainard 1997) arose largely as a consequence of the work of Krugman 
(1991) on positive transportation costs. Brainard (1997) combined positive trade costs with the Markusen (1984) framework of symmetric factor endowments through a trade-off between multinational firm proximity to a destination market and advantages in maintaining plant production abroad to supply the destination market. The absence of factor price differentials forces firms to consider the additional fixed cost of a production plant abroad versus the additional variable cost of continued exports to supply the foreign market.

An extended model, presented in Markusen and Venables (1998) and Markusen and Venables (2000) incorporated Brainard's positive transportation costs, but also allowed for asymmetries between countries due to country size, factor endowments, and technology. Horizontal expansion by multinational firms is driven by an overall large market, and similarities in relative market size, similar labor costs, and high transportation costs and tariffs.

According to the convergence criteria, the integration process is focused on inflation, budgetary, exchange rate, and interest rate convergence. These criteria account for every aspect necessary for monetary, fiscal, and structural stability, yet the effect of these measures on bilateral foreign investment - largely a microeconomic phenomenon - has not been the focus of past empirical research. The following section presents the model used in this empirical analysis and application of the convergence criteria into an econometric framework.

The empirical analysis is based on a variant of the gravity model, commonly used to analyze bilateral trade flows. ${ }^{2}$ The dataset is composed of aggregate annual bilateral flows of foreign direct investment between EU-15 members (Austria, Belgium, Denmark, Finland, France, Germany, Greece, Ireland, Italy, Luxembourg, Netherlands, Portugal, Spain, Sweden, and United Kingdom) from the OECD and are expressed in million euros. There are $\mathrm{N}=$ $14 \times 13=182$ bilateral relations per time period (i.e., aggregated cross-

2 The model was first independently derived by Tinbergen, J. (1962) Shaping the world economy; suggestions for an international economic policy, New York,: Twentieth Century Fund., and Poyhonen, P. (1963) 'A Tentative Model for the Volume of Trade Between Countries', Welwirtschaftliches Archiv 90: 93-99.. For a theoretical background, see Deardorff, A. V. and National Bureau of Economic Research. (1995) Determinants of bilateral trade : does gravity work in a neoclassical world?, Cambridge, MA: National Bureau of Economic Research.. Please see Egger, P. and Pfaffermayr, M. (2004) 'Foreign Direct Investment and European Integration in the 1990s', The World Economy 27: 99-110. for an excellent overview of different estimation techniques that are routinely employed for the gravity models. 
sections). ${ }^{3}$ The data cover the period from 1994 to 2005 , yielding a total sample of $n=182 \times 7=2184$ bilateral observations. Since the dataset includes a few missing observations, the actual dataset is smaller and unbalanced. ${ }^{4}$

The model is estimated using the following gravity equation and includes Hecksher-Ohlin variables (market size, income similarity, factor endowments, and distance) as well as proxies for capturing the European convergence (interest rate difference, budget difference, and debt difference):

$$
\begin{aligned}
& \ln \left(F D I_{i j, t}\right)=\alpha_{s}+\stackrel{+}{\beta}_{1} G_{i j, t}+\stackrel{+}{\beta}_{2} S_{i j, t}+\bar{\beta}_{3} R_{i j, t} \\
& +\bar{\beta}_{4} D_{i j, t}+\bar{\beta}_{5} I R D I F_{i j, t}+\bar{\beta}_{6} B G T D I F_{i j, t} \\
& +\bar{\beta}_{7} D B T D I F_{i j, t}+\lambda_{0} E M U_{t}+\lambda_{1}(G * E M U)_{i j, t} \\
& +\lambda_{2}\left(S^{*} E M U\right)_{i j, t}+\lambda_{3}\left(R^{*} E M U\right)_{i j, t}+\lambda_{4}\left(D^{*} E M U\right)_{i j, t} \\
& +\lambda_{5}\left(I R D I F^{*} E M U\right)_{i j, t}+\lambda_{6}\left(B G T D I F^{*} E M U\right)_{i j, t} \\
& +\lambda_{7}\left(D B T D I F^{*} E M U\right)_{i j, t}+\varepsilon_{i j, t}
\end{aligned}
$$

Where bilateral country pairs are denoted $i j=$ Austria-Belgium, AustriaDenmark,..., UK-Sweden [168], and time $t=1994,1995, \ldots, 2005$ [7].

$E M U$ is a dummy variable that takes a value of zero for every year when both countries in a pair are not EMU members, and one from when both countries in the pair are EMU members. For pairs with countries that are not yet EMU members the value will be zero for the whole sample. This approach will make us able to use these pairs as a de facto control group, an approach that will be reinforced by the interaction variables. Indeed, moreover we interact this dummy variable with the variables representing market size, market similarity, factor endowments, distance, interest rate, differences in budget deficits, and differences in public debts. This helps us isolate whether being an EMU member matters or not compared to not being a member, while using the exogenous variables we specified.

The explanatory variables take the following forms:

${ }^{3}$ For the empirical study, Belgium and Luxembourg are combined yielding 14 member states. The number of bilateral trading partners is always one less than the number of member states because domestic investment is not considered.

${ }^{4}$ Note that 14 cross-sections are missing in the dataset. The majority of these bilateral flows originate from Finland or Ireland, or are destined to Greece. Therefore, $N=168$, and $n=1127$. 


$$
\begin{aligned}
& G_{i j, t}=\ln \left(Y_{i t}+Y_{j t}\right) \\
& S_{i j, t}=\ln \left(1-\left(\frac{Y_{i t}}{Y_{i t}+Y_{j}}\right)^{2}-\left(\frac{Y_{j t}}{Y_{i t}+Y_{j}}\right)^{2}\right) \\
& R_{i j, t}=\left|\ln \left(\frac{g c f_{i t}}{N_{i t}}\right)-\ln \left(\frac{g c f_{j t}}{N_{j t}}\right)\right| \\
& I R D I F_{i j, t}=\mid \text { interest }_{i t}-\text { interest }_{j t} \mid \\
& B G T D I F_{i j, t}=\mid \text { budget }_{i t}-\text { budget }_{j t} \mid \\
& D B T D I F_{i j, t}=\mid \text { debt }_{i t}-\text { debt }_{j t} \mid
\end{aligned}
$$

This model with interaction terms is developed to test for a structural shift in the FDI as a result of a country's entry into the Euro zone ${ }^{5}$.

Expected signs are given above the respective coefficient. ${ }^{6}$ Note that the dependent variable FDI represents the flow value rather than stock measurement more commonly used in empirical analysis. ${ }^{7}$ In this case, FDI flows capture the creation of new linkages between multinational firms and foreign affiliates. ${ }^{8}$ Fixed effects are denoted $\alpha_{s}$, and recognize countryspecific (symmetric) heterogeneity, but homogeneity when $I=j$ (i.e. when $I$ $=$ Austria or $j=$ Austria, then the dummy variable takes a value of 1 , and zero otherwise). Therefore, heterogeneity models country-specific participation or investment intensity instead of modeling heterogeneity between source and host countries. ${ }^{9}$ The error term, $\varepsilon_{i j, t}$, represents all unobserved bilateral

${ }^{5}$ The convergence period started in 1993 and finished in 1998. We start in 1994, however not using 1993 should not be an issue, since the relevant years for the entry into the EMU were 1997 and 1998.

${ }^{6}$ An exchange rate variable and an absolute inflation rate variable were included in the initial analysis to account for all Maastricht Treaty criteria. Both variables yielded statistically insignificant results and were excluded from the final model.

${ }^{7}$ See Brenton, P., Di Mauro, F. and Lucke, M. (1999) 'Economic Integration and FDI: An Empirical Analysis of Foreign Direct Investment in the EU and Central and Eastern Europe', Empirica 26: 95-121., and Egger, P. and Pfaffermayr, M. (2004) 'Foreign Direct Investment and European Integration in the 1990s', The World Economy 27: 99-110. for empirical research employing FDI stock values.

${ }^{8}$ The dependent variable for FDI is in log form, reflecting only positive investment; disinvestment is recorded as 0 . A value of 1 is added to each FDI value to avoid $\ln (0)$.

This does not bias the estimates as $\ln \left(1+F D I_{i j, t}\right) \approx \ln \left(F D I_{i j, t}\right)$ when $F D I_{i j, t}$ is large. But, where $\ln \left(F D I_{i j, t}\right)=0$, then $\ln \left(F D I_{i j, t}+1\right)=0$.

${ }^{9}$ For a generalized fixed effects gravity model, see Baltagi, B. H., Egger, P. and Pfaffermayr, M. (2003) 'A Generalized Design for Bilateral Trade Flow Models', Economics Letters 80(3): 391-397.. 
effects. The three Hecksher-Ohlin variables (G, S, R) resemble the Helpman (1987) specification and are detailed below.

$\mathrm{G}$ is the measure of "market size" (see table 1) or overall "economic space". Therefore, it serves as a proxy for investment that is motivated by marketexpansion reasons (Helpman 1987). The expected value is positive for investment flows under circumstances of horizontal firm integration.

$\mathrm{S}$ is an index that captures the relative size of the two economies that is bounded between absolute divergence in size and equality in country size, called "market similarity" (see table 1 ). If two countries have roughly equal GDP, the coefficient approaches $-0.69=\ln (0.5)$. Perfect dissimilarity yields a coefficient value that approaches $\ln (0) .{ }^{10}$ A positive coefficient is evidence of horizontal firm integration, as presented by Brainard (1997) and Markusen and Venables (1998). Similarity in country size is one of the main theoretical determinants of multinational expansion to determine market similarity.

$\mathrm{R}$ measures the relative difference between the two countries in terms of relative "factor endowments" (see table 1). $\mathrm{R}$ in this study is the ratio of gross fixed capital formation and country population. The factor endowments variable takes a minimum value of 0 , representing equality in relative factor endowments, and a maximum value that approaches 1, the largest possible difference in relative factor endowments. As mentioned in the preceding section, the importance of factor endowments varies significantly depending on the trade theory hypothesis examined. Horizontal firm integration theory dictates that factor endowment differences are irrelevant and should not be significant (or even exist) among developed countries. As the EU represents a set of well-developed and relatively wealthy countries, movement toward equalization of relative factor endowments is expected to yield an increase in bilateral FDI outflows.

D denotes the $\log$ of the "distance" (see table 1) between the economic centers of the two countries. Broadly speaking, distance is a proxy for trade and transportation costs, which has a negative impact on investment and trade flows. Markusen and Venables (2000) argue that distance is not relevant, but transportation costs are important for entry of multinational firms. Investment that promotes production for the foreign market a priori should not be greatly influenced by distance. Yet, if distance and transportation costs are inextricably linked, the coefficient on D should be

\footnotetext{
${ }^{10}$ In the case of a country pair approaching perfect dissimilarity, the coefficient approaches $\infty$.
} 
negative. The costs associated with distance, such as communication and coordination costs, reduce incentives to new investment. ${ }^{11}$

IRDIF is the difference in "interest rates" (see table 1) between country $I$ and $j$. The interest rate measures the long-term cost of borrowing. A negative coefficient is expected. Financing of assets and affiliate purchases is likely to come from both the source or target country; convergence in rates of both markets would see an increase in investor confidence and positive FDI flows. In other words, convergence could likely result in tight correlation of the interest rates.

BGTDIF represents the difference in the government "budget surplus or deficit" as a percentage of GDP (see table 1) between the source and host country. A convergence in the balance of the budget surplus is expected to increase investment. The intuition behind the expectation is clear: the variable attempts to capture the effect of government fiscal responsibility. Presumably, a multinational firm wishing to expand horizontally will be induced to invest in a market characterized by a similarity in government finances relative to the source country.

DBTDIF is the difference of the "debt-to-GDP ratio" between each country pair (see table 1). This variable represents long-term stability of the government. Since FDI is considered a long-term transaction (as compared to exports, for example), a reduction in the debt differential between countries is likely to lead to an increase in investment flows.

Given the longitudinal nature of data, a simple OLS estimate of our model imposes strict restrictions that might not be justifiable given the complicated nature of our dataset. Specifically, we expect both temporally dependent interactions as well as interactions between country panels that contradict OLS assumptions. The presence of serial correlation and panel heteroscedasticity were of key concern in our estimation of this the model.

A way to check for autocorrelation is to use Baltagi and Wu (1999)'s LBI test or a modified Durbin-Watson test for unequally spaced panel data (Bhargava et al. 1982). If there is autocorrelation, the option would be fourfold: (1) a dynamic panel model (two-way random effect model or errorcomponent model) with first differences, sometimes known as a Prais-

\footnotetext{
${ }^{11}$ It is worthwhile to point out that if horizontal FDI is aimed as a substitute for exports due in part by higher transportation costs, then the expected value should be positive. This argument is in line with theory presented in Markusen, J. R. and Venables, A. (1998) 'Multinational Firms and the New Trade Theory', Journal of International Economics 46: 183-203.. This study does not look at lower FDI transportation costs relative to bilateral trade transportation costs; instead, the variable is focused on measuring significance of absolute barriers to investment.
} 
Winston transformation or a Cochrane-Orcutt transformation; (2) a dynamic model with lagged dependent variables with two slightly different approaches known as one or two step general methods of moments (GMM) estimators as in Arellano and Bond (1991) or Arellano and Bover (1995) ${ }^{12}$; (3) a weight-adjusted combination of the White and Newey-West estimator to handle both the heteroskedasticity and the autocorrelation in the model; or (4) a feasible generalized least squares procedure (FGLS, or a two-state generalized least squares model) as in Parks (1967) and Kmenta (1997) in which the model assumes an autoregressive error structure of the first order $\mathrm{AR}(1)$, along with contemporaneous correlation among cross-sections.

The initial set of OLS estimates was subject to several tests to determine the interaction between observations. The assumption of zero autocorrelation was rejected by the Baltagi and Wu (1999)'s LBI test, while the modified Bhargava et al. (1982) Durbin-Watson proved inconclusive for positive serial correlation. Therefore the fourth option above was chosen. The model was estimated using the cross-sectionally heteroscedastic and time-wise autoregressive model (Kmenta 1997). Unlike pooled OLS estimation, the Kmenta-Parks method employed here accounts for heteroskedasticity and serial correlation when present. ${ }^{13}$

The Kmenta-Parks model is slightly modified. When $\mathrm{T}<\mathrm{N}$ (here $\mathrm{T}=12$ and $\mathrm{N}=168)$ the following assumption is necessary: $E\left(\varepsilon_{i j, t}, \varepsilon_{j i, t}\right)=0$, thereby removing the assumption of contemporaneous correlation among crosssections.

While our choice of estimation method is not immune to criticism, such as those found in Beck and Katz (1995), the modified FGLS estimates here perform best because of our concern for autocorrelation. One of the main

12 GMM is usually robust to deviations of the underlying data generation process to violations of heteroskedasticity and normality, insofar as they are asymptotically normal, but they are not always the most efficient estimators.

${ }^{13}$ First, OLS is used to obtain the regression residuals, which are then used to obtain a transformation that has an asymptotically non-autoregressive and homoscedastic error term. The other characteristics if the general Kmenta-Parks model are as follows:

$$
\begin{aligned}
E\left(\varepsilon_{i j, t}\right) & =\sigma_{i j}^{2} \text { (heteroscedasticity) } \\
E\left(\varepsilon_{i j, t}, \varepsilon_{j i, t}\right) & =0(\text { where } i j \neq j i \text { denotes cross - sectional independence) } \\
\varepsilon_{i j, t} & =\rho \varepsilon_{i j, t-1}+\mu_{i j, t} \\
\mu_{i j, t} & \sim N\left(0, \sigma_{\mu_{j}}^{2}\right) \\
\varepsilon_{i j, t} & \sim N\left(0, \frac{\sigma_{\mu_{j}}^{2}}{1-\rho^{2}}\right) \\
E\left(\varepsilon_{i j, t-1}, \mu_{j i, t}\right) & =0 \forall i j, j i
\end{aligned}
$$


criticisms of the Kmenta-Parks estimates is the possibility of underestimation of standard errors and consequently resulting in an artificially inflated statistical significance. Since the FGLS method could be employed either in a fixed effects or random effects framework depending up on the underlying behavior of cross-sectional heterogeneity, it is critical that an appropriate test be conducted before proceeding with the suitable estimation strategy. ${ }^{14}$

Lastly, we detail the data sources of the variables. FDI outflow data are from the OECD. The flow of FDI is cross-border investment in which the investor has a long-term interest in an enterprise or market in another economy. Investment is composed of two parts: equity capital and other capital. Equity capital includes all branches and ordinary shares in subsidiaries and associates. Other capital is comprised of inter-company debt, such as loans and trade credits, between the investor and the subsidiary (branch or associate). Data are weighted with 2000 as the base year by the CPI provided by Ameco (European Commission).

GDP data are taken from Ameco (European Commission) and expressed in million euros using Purchasing Power Parity (PPP) rates. Data are also converted to a 2000 base year through the CPI provided by Ameco. The total labor force (used in the capital per worker ratio) is defined as the economically active population that contributes to the production of goods and services in the formal economy. The variable was obtained from the World Bank.

Distance data were obtained from Jon Haveman's Website. ${ }^{15}$ The variable is defined as the distance between the economic center of one country to another. Note that this does not lead to a value of 0 when countries are adjacent to each other. In the empirical study, we loosely follow Polak (1996) who addresses the built-in bias of the gravity model that is

14 According to the Hausman specification test, the cross-sectional heterogeneity can be treated as random, if the null hypothesis $\mathrm{H}_{0}: E\left(\mathbf{Z}_{i j, t}^{\prime}, \varepsilon_{i j, t}\right)=0$ can not be rejected, signifying a lack of correlation between the explanatory variables and the disturbance term. However, with $\chi_{7}^{2}=61.6$ which is significant at $<.01$ level, the stated null hypothesis could be rejected, signifying correlation between the explanatory variables and the disturbance term. Accordingly, a fixed effects model is preferred. The reported test statistic is based on our sample employed in Table 1 empirical analysis. This finding is in accordance with Egger, P. and Pfaffermayr, M. (2004) 'Foreign Direct Investment and European Integration in the 1990s', The World Economy 27: 99-110.. Specifically, the cross-sectional heterogeneity dimension is captured by employing 13 symmetric dummies given a total of 14 countries included in the sample. As suggested by Greene, W. H. (2003) Econometric analysis, Upper Saddle River, N.J.: Prentice Hall., a maximum likelihood estimation method is employed for obtaining the FGLS estimates reported in Table 1.

${ }^{15} \mathrm{http} / / /$ www.macalester.edu/research/economics/page/haveman/trade.resources/

TradeData.html 
"downward" for "far-away countries" and "upward" for "close-up countries." The solution is to make the distance variable relative to the size of the host country economy. The variable therefore, is weighted by the host country population.

Interest rates represent central government bond yields on the secondary market with a residual maturity of 10 years (Eurostat). Budget surplus/deficits as a percentage of a country's GDP were obtained from Eurostat. The budget of the consolidated central government includes operations of budgetary central government, extra budgetary units, and social security funds. Debt data are compiled by Eurostat. Debt is defined as consolidated gross debt of the central government and sub sectors including state government, local government, and social security debt. The econometric analysis and discussion of the results are presented in the next section.

\section{IV.}

\section{Interpretation of the results}

We propose to look at the results through two steps: the European convergence variables and interaction variables, and the country fixed effects. 
Table 1: FGLS Estimates 1994-2005 [Double-Log Specification]

Dependent Variable:

$\ln ($ FDI) . Mean: 5.546547 , Std. Dev: 2.610153

\begin{tabular}{lllll}
\hline \multicolumn{1}{c}{ Variable } & Mean & Std. Dev. & Coefficient & z-value \\
\hline Hecksher-Ohlin Variables & & & & \\
G (Market Size) & 13.870970 & 0.748909 & 4.314855 & $8.42 * * *$ \\
S (Market Similarity) & -1.196138 & 0.475701 & 2.226209 & $8.23 * * *$ \\
R (Factor Endowment) & 0.293574 & 0.217749 & -0.549432 & $-2.15^{* *}$ \\
D (Distance) & 4.166783 & 1.348870 & -0.374466 & $-6.25^{* * *}$
\end{tabular}

European Convergence Variables

IRDIF (Interest Rate)

BGTDIF (Budget)

DBTDIF (Debt)

$\underline{\text { EMU dummy }}$

Interaction variables

G*EMU
S*EMU
R*EMU
D*EMU
IRDIF*EMU
BGTDIF*EMU
DBTDIF*EMU

Country Fixed Effects

Austria

Belgium/Luxembourg

Denmark

Finland

France

Germany

Greece

Ireland

Italy

Netherlands

Portugal

Spain

Sweden

Constant

$n=1127$

${ }^{*}<.1$ significance

** $<.05$ significance

$*^{* * *}<.01$ significance

$\begin{array}{llll}0.703530 & 1.204998 & 0.043582 & 1.37 \\ 2.541130 & 1.866821 & 0.006072 & 0.31 \\ 22.975110 & 22.312020 & -0.008472 & -3.22^{* * *} \\ & & & \\ 0.333628 & 0.471717 & -6.075481 & -2.28^{* *} \\ & & & \\ & & & \\ 4.651068 & 6.588521 & 0.400897 & 2.27^{* *} \\ -0.390779 & 0.611815 & 0.578531 & 3.04^{* *} \\ 0.089800 & 0.171809 & 0.092518 & 0.21 \\ 1.382250 & 2.109920 & 0.272843 & 3.30^{* * *} \\ 0.036540 & 0.073691 & 1.114270 & 2.6^{* * *} \\ 0.946514 & 1.816619 & -0.073306 & -2.72^{* * *} \\ 8.975993 & 18.309360 & 0.006400 & 2.34 *\end{array}$

$\begin{array}{llll}0.165049 & 0.371388 & 1.826345 & 3.47 * * *\end{array}$

$\begin{array}{llll}0.070609 & 0.256284 & 4.394779 & 9.62 * * *\end{array}$

$\begin{array}{llll}0.148279 & 0.355533 & 4.320902 & 7.00 * * *\end{array}$

$\begin{array}{llll}0.082966 & 0.275952 & 3.323161 & 4.95 * * *\end{array}$

$\begin{array}{lllll}0.179170 & 0.383664 & -0.116105 & -0.97\end{array}$

$\begin{array}{llll}0.178288 & 0.382924 & -0.238437 & -1.81 *\end{array}$

$\begin{array}{llll}0.063548 & 0.244054 & 1.600035 & 2.82 * * *\end{array}$

$\begin{array}{llll}0.096205 & 0.295002 & 5.818056 & 8.08 * * *\end{array}$

$\begin{array}{llll}0.182701 & 0.386592 & -0.788204 & -5.24 * * *\end{array}$

$\begin{array}{llll}0.172992 & 0.378407 & 2.997415 & 8.34 * * *\end{array}$

$\begin{array}{llll}0.177405 & 0.382180 & 2.031531 & 3.38 * * *\end{array}$

$\begin{array}{llll}0.173875 & 0.379169 & 0.310433 & 1.45\end{array}$

$\begin{array}{lllll}0.138570 & 0.345650 & 4.070427 & 7.83 * * *\end{array}$

$-53.272140-7.16^{* * *}$ Likelihood Ratio $\quad-1588.169 * * *$ 


\subsection{European Convergence Variables}

Being an EMU member more specifically means that these countries converge. The European convergence seen through the usage of the common currency matters: once a country enters into the Euro zone, market size of the two countries, market similarity, and distance are significant. In other words, a converging Europe measured through the use of the Euro reinforces the attractiveness of the Euro zone in terms of FDI. Convergence occurs at different levels: at the structural policy level, and at the fiscal level.

Our results suggest that a convergence in the long-term interest rate in the source and host countries does not affect multinational firms for the overall sample (see table 1). However, convergence in terms of interest rate leads to lower FDI flows for the EMU mmbers after 1999 (or at the date of their entry). Indeed, convergence in the long-term interest rate is a sign of a convergence in the structural policies among the EMU countries. In this case, this result suggests that the structural similarity of the countries reduces the interest to invest in these countries.

However, there is also a "reassuring" effect of a European convergence when it comes to the fiscal policy. Management of government debt is determinant of FDI flows for the overall sample: convergence in public debts is significant and negative. Convergence in public debts seems to slightly reassure the investors of a sound situation by raising FDI attractiveness. This 'reassuring' effect is reinforced by the results based on the interaction variables (see equation (3)): once in the Euro zone, FDI seem to flow between EMU countries with a greater difference in debt levels, while market size is still significant, as well as market similarity. This change in sign for the debt variable may find its explanation into the study of deficits. Within the Euro zone, convergence in public deficits are now significant. Convergence in public deficits - constrained by the Stability and Growth Pact - leads to a rise in FDI. Investors indeed seem to be reassured by the homogenization of fiscal policies.

From equation (1), the EMU effect can be obtained by partially differentiating $\ln (\mathrm{FDI})$ with respect to "EMU":

$$
\begin{aligned}
& (\partial L F D I / \text { deuro })=\lambda_{0}+\lambda_{1}(G)_{i j, t}+\lambda_{2}(S)_{i j, t} \\
& +\lambda_{3}(R)_{i j, t}+\lambda_{4}(D)_{i j, t}+\lambda_{5}(I R D I F)_{i j, t} \\
& +\lambda_{6}(B G T D I F)_{i j, t}+\lambda_{7}(D B T D I F)_{i j, t}
\end{aligned}
$$

This equation leads to: 


$$
\begin{aligned}
& (\partial L F D I / \text { deuro })=-6.07+.4008(13.87) \\
& +0.5785(-1.196)+.0925(.293) \\
& +.2728(4.166)+1.114(.703) \\
& -.0723(2.54)+.0064(22.975)=.7075
\end{aligned}
$$

This result suggests that belonging to the EMU has a strong effect on FDI from EMU countries to other EMU countries. Our estimation suggests that FDI flows double in this context (an increase of $102 \%$ ). ${ }^{16}$ This number is interesting to consider in line with the results found by Frankel and Rose (2002) who suggest that trade has tripled among currency union members. When it comes to FDI, we show with our interaction model that Mundell's intuition was right, as well as provide an empirical assessment to De Grauwe and Mongelli (2005)'s "intuition" about the rise of FDI in Europe when countries belong to the EMU.

Another interesting point is distance. Distance for countries within the Euro zone play an interesting role here: the farther the host EMU country the better. So this result suggests that within the Euro zone, investors seem to be reassured by the adhesion to the EMU and care less about proximity (see Figure 1). Indeed, one could note from our results that the interaction between distance and the EMU dummy (D*EMU) is positive (.272843 with a significant $\mathrm{z}$-value) even though the overall effect is still negative ($.374466+.272843=-.101623)$. In other words, the 'gravity' feature is still there: proximity in the overall sample matters displaying gravity, but once in the Euro zone 'anti-gravity' forces appear. This result is reinforced by the fact that eventually convergence in factor endowments do not seem to matter anymore once in the Euro zone.

${ }_{16}\left(e^{0.7075}-1\right)=1.02891$ (i.e., $102.891 \%$ ). Given the $\log$-lin nature of the empirical model, the coefficients scaled as $\left(e^{\beta}-1\right)$ could be interpreted as partial elasticities (i.e., a resulting percentage change in FDI flows when all countries - sources and hosts - are EMU members). 


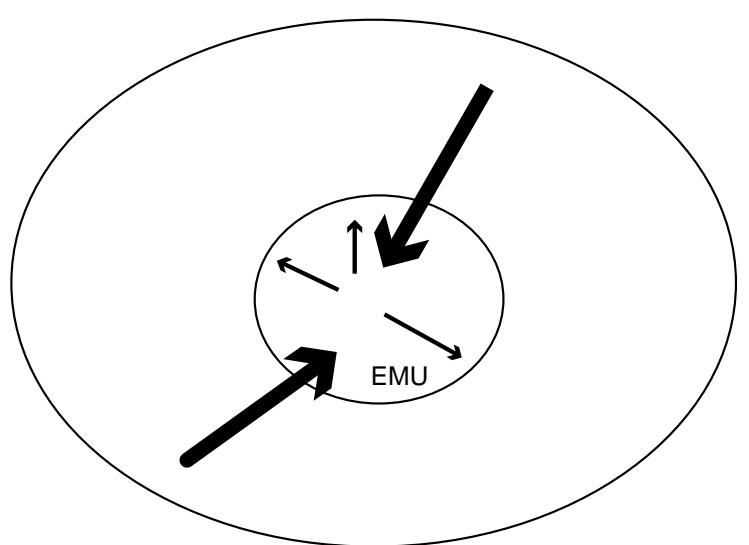

Figure 1. Gravity and anti-gravity

\subsection{Country Fixed Effects}

Lastly, we briefly mention the symmetric country dummy variables that proxy country participation (both inflow and outflow) of FDI within the region. Interestingly, the most active countries in terms of multinational investment during the period observed have been Ireland, Belgium/Luxembourg, and Denmark for the overall period (see table 1). These findings are plausible as, comparatively speaking; the home markets of these countries are small relative to those of the region's larger economies. Consequently, multinational firms based in those countries would be the most willing to expand to other markets.

\section{V.}

\section{Policy Implications and Conclusions}

The primary results of this empirical analysis find evidence of growing horizontal integration of the EU-15 based predominantly on market access and consumer income. These intra-industry linkages are the main factors that deepen market integration and allow for synchronization of demand and trade-based shocks. The magnitude of the Hecksher-Ohlin variables, specifically market size and income similarity, allows for a more visible role in determining the creation of horizontal linkages. Europe is indeed becoming an optimum currency area in terms of allocation of capital as formulated in Mundell (1973).

Defined in terms of allocation of capital, convergence thus seems to have occurred. This supports the European Commission (1990)'s view, instead of Krugman (1993)'s comparative argument. 
The convergence process of the European member states in the 1990s presents several factors that will guide the future entry of member countries into the monetary union. In May 2004, the European Union expanded to include ten Central and Eastern European accession candidates. The findings here suggest key characteristics that are necessary to attract intra-EU multinational investment during their accession into the EMU.

Recent studies by Brenton et al. (1999) and Janicki and Wunnava (2004) show that trade between the European Union and these accession candidates is still based primarily on differences in factor endowments - such as labor costs - where production is aimed at re-export back to the EU market, rather than consumption in the candidate countries. Brenton et al. (1999) refer to this as the integration of the accession candidates into the European production process. The results presented here, however, suggest that the structure of current EU production process is quite different. The entry of the accession candidates into the EMU will depend not on the timetable presented by the European Commission; entry will depend on the development of intra-industry linkages and the continued creation of horizontal intensity of investment.

Future empirical research could be useful in further exploring the convergence hypothesis presented in Markusen and Venables (1996). Specifically, the results here follow the hypothesis suggesting growth in multinational firms is determined by convergence of income levels, relative factor endowments, and size. A future analysis of intra- European imports and exports in modeling domestic firm behavior might be useful in finding further support of European convergence relative to growth in multinational firm activity. 


\section{References}

Arellano, M. and Bond, S. (1991) 'Some Tests of Specification for Panel Data: Monte Carlo Evidence and an Application to Employment Equations', Review of Economic Studies 58: 277-297.

Arellano, M. and Bover, O. (1995) 'Another Look at the InstrumentalVariable Estimation of Error-Component Models', Journal of Econometrics 68(1): 29-52.

Baltagi, B. H., Egger, P. and Pfaffermayr, M. (2003) 'A Generalized Design for Bilateral Trade Flow Models', Economics Letters 80(3): 391-397.

Baltagi, B. H. and Wu, P. X. (1999) 'Unequally Spaced Panel Data

Regressions with AR(1) Disturbances', Econometric Theory 15: 814823.

Barrel, R. and Pain, N. (1997) 'The Growth of Foreign Direct Investment in Europe', National Institute Economic Review 0: 63-75.

Beck, N. and Katz, J. N. (1995) 'What To Do (and Not To Do) with TimeSeries Cross-Section Data', American Political Science Review 89: 634-647.

Bhargava, A., Franzini, L. and Narendranathan, W. (1982) 'Serial Correlation and the Fixed Effects Model', The Review of Economic Studies 49(4): 533-549.

Brainard, S. (1997) 'The Empirical Assessment of the ProximityConcentration Trade-Off Between Multinational Sales and Trade', The American Economic Review 87: 520-544.

Brenton, P., Di Mauro, F. and Lucke, M. (1999) 'Economic Integration and FDI: An Empirical Analysis of Foreign Direct Investment in the EU and Central and Eastern Europe', Empirica 26: 95-121.

De Grauwe, P. and Mongelli, F. P. (2005) 'Endogeneities of Optimum Currency Areas: What Brings Countries Sharing a Single Currency Closer Together?' ECB Working Paper Series 468.

Deardorff, A. V. and National Bureau of Economic Research. (1995) Determinants of bilateral trade : does gravity work in a neoclassical world?, Cambridge, MA: National Bureau of Economic Research.

Egger, P. and Pfaffermayr, M. (2004) 'Foreign Direct Investment and European Integration in the 1990s', The World Economy 27: 99-110.

European Commission (1990) 'One Market One Money', European Economy 44.

Feenstra, R. (1999) 'Facts and Fallacies about Foreign Direct Investment', In Feldstein, M. (ed.), International Capital Flows, Chicago: University of Chicago Press and NBER, p.`pp. 331-350.

Frankel, J. A. and Rose, A. K. (1998) 'The Endogeneity of the Optimum Currency Area Criteria', Economic Journal 108: 1009-1025. 
Frankel, J. A. and Rose, A. K. (2002) 'An Estimate of the Effect of Common Currencies on Trade and Income', The Quarterly Journal of Economics CXVII: 437-466.

Greene, W. H. (2003) Econometric analysis, Upper Saddle River, N.J.: Prentice Hall.

Helpman, E. (1984) 'A Simple Theory of International Trade with Multinational Corporations', Journal of Political Economy 92: 451471.

Helpman, E. (1987) 'Imperfect Competition and International Trade: Evidence from Fourteen Industrial Countries', Journal of the Japanese and International Economies 1: 62-81.

Helpman, E. and Krugman, P. (1985) Market Structure and Foreign Trade, Cambridge: MIT Press.

Janicki, H. and Wunnava, P. (2004) 'Determinants of Foreign Direct Investments: Empirical Evidence from EU Accession Candidates', Applied Economics 36: 505-509.

Kmenta, J. (1997) Elements of Econometrics, Michigan: University of Michigan Press.

Krugman, P. (1993) 'Integration, Specialization and Regional Growth: Notes on 1992', In Torres, F. and Giavazzi, F. (eds.), Adjustment and growth in the European Monetary Union, Cambridge: Cambridge University Press.

Krugman, P. R. (1991) Geography and trade, Leuven, Belgium Cambridge, Mass.: Leuven University Press; MIT Press.

Markusen, J. R. (1984) 'Mutlinationals, Multi-Plant Economies, and the Gains from Trade', Journal of International Economics 16(3-4): 205226.

Markusen, J. R. and Venables, A. (1996) 'The Increased Importance of Direct Investmet in North Atlantic Economic Relationships: A Convergence Hypothesis', In Canzoneri, M., Ethier, W. and Grilli, V. (eds.), The New Transatlantic Economy, Cambridge: Cambridge University Press, p.^pp. 169-189.

Markusen, J. R. and Venables, A. (1998) 'Multinational Firms and the New Trade Theory', Journal of International Economics 46: 183-203.

Markusen, J. R. and Venables, A. (2000) 'The Theory of Endowment, IntraIndustry and Multi-National Trade', Journal of International Economics 52: 209-234.

Mundell, R. (1973) 'A Plan for a European Currency', In Johnson, H. G. and Swoboda, A. K. (eds.), The Economics of Common Currencies: Allen and Unwin, p.`pp. 143-172.

Parks, R. W. (1967) 'Efficient Estimation of a System of Regression Equation When Disturbances are Both Serially and Contemporaneously Correlated', Journal of the American Statistical Association (62): 500-509. 
Polak, J. (1996) 'Is APEC a Natural Regional Trading Block? A Critique of the Gravity Model of International Trade', The World Economy 19: 533-543.

Poyhonen, P. (1963) 'A Tentative Model for the Volume of Trade Between Countries', Welwirtschaftliches Archiv 90: 93-99.

Tinbergen, J. (1962) Shaping the world economy; suggestions for an international economic policy, New York,: Twentieth Century Fund. 